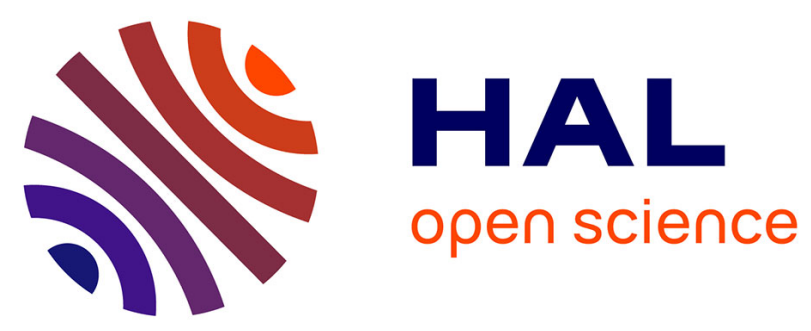

\title{
Religious organisations as investors: a Christian perspective on shareholder engagement
}

Katinka C. van Cranenburgh, Daniel Arenas, Jennifer Goodman, Céline

Louche

\section{- To cite this version:}

Katinka C. van Cranenburgh, Daniel Arenas, Jennifer Goodman, Céline Louche. Religious organisations as investors: a Christian perspective on shareholder engagement. Society and Business Review, 2014, 9 (2), pp.195-213. 10.1108/SBR-11-2013-0078 . hal-01067933

HAL Id: hal-01067933

https://hal-audencia.archives-ouvertes.fr/hal-01067933

Submitted on 23 Dec 2014

HAL is a multi-disciplinary open access archive for the deposit and dissemination of scientific research documents, whether they are published or not. The documents may come from teaching and research institutions in France or abroad, or from public or private research centers.
L'archive ouverte pluridisciplinaire HAL, est destinée au dépôt et à la diffusion de documents scientifiques de niveau recherche, publiés ou non, émanant des établissements d'enseignement et de recherche français ou étrangers, des laboratoires publics ou privés. 


\title{
RELIGIOUS ORGANISATIONS AS INVESTORS:
}

\section{a Christian Perspective on Shareholder Engagement.}

\author{
Katinka C. van Cranenburgh, ESADE Business School, Ramon Llull University \\ Daniel Arenas, ESADE Business School, Ramon Llull University \\ Jennifer Goodman, ESADE Business School, Ramon Llull University \\ Céline Louche, Audencia School of Management
}

\begin{abstract}
Purpose

The purpose of this paper is to deepen the discussion about religious organisations' (ROs) potential to practise their faith by means of their investments, rather than keeping both issues separate.
\end{abstract}

\section{Design/methodology/approach}

The authors adopted a qualitative exploratory approach using seven cases of social shareholder engagement (SSE) by Christian organisations. It focused on creating knowledge from best practices.

\section{Findings}

Within the three Christian organisations studied, the authors identified three significant features that relate to their religious nature and affect their SSE: having a structured belief system, a grassroots network and a long-term perspective. These features can be instrumental in impacting company behaviour and society at large.

\section{Research limitations/implications}

The authors chose three ROs for their relevance and comparative features, but this limited sample size makes it hard to generalise the research findings.

\section{Practical implications}

This paper invites ROs to review their potential for actively owning their shares to be consistent with their faith and create change in business and society at large. Besides, ROs, with their unwavering belief system, extensive grassroots networks and long-term approach, are a force in the shareholder engagement field to be reckoned with by business.

\section{Originality/value}

The paper presents multi cases of ROs active in using their investments to create change in companies and society at large. 


\section{Introduction}

Various Religious Organisations (ROs) strive to make the companies they invest in more socially responsible by practising social shareholder engagement (SSE). The extent to which the religious nature of ROs comes into play when they undertake SSE remains unclear (Booth, 1993; Duncan et al. 1999), despite their sizeable financial investments and their stress on practising SSE (Louche et al., 2012). Thus, the following question guided the exploratory qualitative case studies of three ROs of the Christian denomination engaging in SSE presented in this chapter:

What are the features influencing the SSE practices of Christian organisations and how are these features related to their religious nature?

By answering this question, we challenge a dichotomy that is commonplace in literature: the so-called sacred-secular divide of ROs religious beliefs and their financials. The first section sets the context by exploring the features of ROs, including the main Christian sources on investing and SSE. The section further outlines the features influencing SSE found in the literature, and lastly establishes a relationship between the actors (Christian organisations) and the topic (SSE). The next section covers methodology, data gathering and analysis. The way the religious nature affects Christian organisations' SSE practices is discussed. Conclusions are then drawn, the limitations of the study identified and suggestions made for future research.

This chapter makes two major contributions. First, we showcase three Christian organisations where religion and investing are intertwined - thus responding to Kreander et al. 's (2004) call to challenge the assumed sacred-secular divide of religious organisations and their financials. Second, this chapter presents similarities and differences between the influencing features of SSE found in our empirical study and those in the literature, highlighting three features that indicate the potential for Christian organisations to practise their belief through means of their investments: having a structured belief system, a long term perspective and a grassroots network, all of which stem from their religious nature.

\section{Setting the Context}

Religious investors have been called the third largest group of investors in the world (UN, 2009); yet, surprisingly little is known about their investment practices. While religious leaders believe that investing implies values (Kreander et al., 2004; Sparkes and Cowton, 2004) and ROs are known to consider SSE as a tool for investing responsibly (Louche et al., 2012), the link between the religiosity of ROs and SSE 
remains unexplored. As ROs are an important part of the worldwide investment community, we help redress the relative lack of knowledge on faith consistent investing.

\section{Religious Organisations}

ROs vary in several ways, not least in religious traditions, denominations, geographical presence and governance structures. Generally, ROs' main tasks are the upkeep of places of worship, managing (religious) staff, providing guidelines for living and spreading the word of God(s). They do these activities thanks to a certain infrastructure. In the sociological literature, ROs are considered to exemplify organisations with significant social capital which is thought to underpin the community and benefit its members (Leavey and King, 2007). In the religious literature, Stark (1996) stresses the ROs' doctrine as justification for their authority as well as the considerable commitment shown by members of the religious communities. The early Christians had a communal understanding of shared ownership and stewardship, derived from the Acts of the Apostles, stating "The community of believers were of one heart and mind. None of them ever claimed anything as his own; rather everything was held in common" (Acts of Apostles, chapter 3, 2:44). For a long time, accumulation of wealth and using money for the sake of gaining interest was not accepted and seen as shameful. Commercial partnerships were set up equally whereby failures or successes in investments were equally shared amongst the partners (Noonan, 1957). In this way, the dilemmas occurring with the concept of usury and interest were avoided and sharing risks and responsibilities was a community or partnership exercise that was in compliance with the religious beliefs. As economic activity and capitalism evolved, religious reformers limitedly but increasingly allowed financial constructions that resulted in individual profits. Max Weber (1920), writing on Protestant ethics and capitalism, elaborates extensively on Richard Baxter's (1825) 'A Christian Directory', seen as religious ethical guidelines for practical and economic life. Baxter (1825; p122) mentions "that if God provides chances for gaining profit, He must have his reasons for doing so" Profits should be made without damage to the soul or to others and should be legitimate". This is actually a 'calling' that should be adhered to in being a proper steward of God. Weber frames proper stewardship in terms of labour, whether practised by an artisan or a business man, as long as one works hard and does not misuse wealth gained by labour. One should accept his gifts [the profits] as a form of grace and be willing to utilise them when and if God wants it. Thus, from an original total ban on usury the religious community slowly but steadily accepted different forms of financial products. Church members could earn money and generate wealth, provided that it was not to satisfy ego but for the glory of God.

Similarly, in Judaism, we find that the source of a person's wealth is not morally neutral, although the acquisition of wealth is seen as a legitimate activity in itself. The Torah reads it is unacceptable to make money from lending on interest to a fellow Jew. Similarly in the Islamic tradition, according to the Quran interest ('riba') is prohibited. The Quran says "God deprives interest of all blessings but blesses charity". Cornuel et 
al (2010) refer to the historical and continuous debate between the uncompromising orthodox trend and a liberal reformist approach towards money and religion. ROs continue to struggle formalizing their opinion about the limitations of financial investments (Louche, et al, 2012) but the route towards the liberal approach has gained momentum.

Today, ROs are funded by economic activities, membership fees, donations and legacies. ROs may establish pension funds, healthcare insurance and funeral funds for their staff and members. While the financial structures vary greatly, funds are also used for various purposes (staffing, housing, places of worship, serving members and deprived communities). Managing large sums of money implies investing, which in turn raises the question of responsible and faith-consistent investing. A Methodist Church for example, might easily exclude investments in arms based on its non-violent peaceoriented faith principles; however, it also can apply values of integrity arising in the banking sector, fairness in terms of executive remuneration, human trafficking in the hospitality industry, responsibility in the extractive industry and various other values to its investment portfolio. With a fund size around 400 million euros in the UK alone (Central Finance Board, 2013), the Methodist Church, with an expected 75 million community members worldwide (Cracknell and White, 2005), manages money in several states around the world.

\section{Features Influencing Social Shareholder Engagement}

In this study we focus on the features influencing SSE. We use the word 'features' rather than 'factors', 'resources' or 'characteristics' to be as inclusive as possible. Also, we chose to be consistent with Arjaliès (2010) who studied how socially responsible investment movements can bring concerns into financial institutions. She identified four features namely having a collective identity, sharing individual resources in the pursuit of a common purpose, aiming to change existing institutions and providing a new orientation for society $(2010 ; 59)$. We adopted this term without necessarily categorizing ROs practising SSE as a form of social movement.

SSE represents roughly $€ 2$ trillion in Europe and the same again in the US (Eurosif, 2012; USSIF, 2010). One of the main objectives of SSE is to influence companies' social, environmental, and ethical issues (Eurosif, 2006; Goodman, et al, forthcoming) and it includes practices such as shareholder resolutions, private and public dialogue between management and shareholders, as well as initiatives by coalitions of shareholders (Lydenberg, 2007). Threatening with divestment - the sale of shares by dissatisfied shareholders - is also viewed as an engagement tool (Admati and Pfleiderer, 2009). The number of actors involved in SSE has increased in recent years and covers a broad range: pension funds (Barber, 2007; Clark \& Hebb, 2004), NGOs (Guay, et al, 2004; Riyanto and Toolsema, 2007; Waygood and Wehrmeyer, 2003), ROs (Proffitt and Spicer, 2006), and unions (Anderson et al., 2007; Marens, 2004). 
The various features influencing SSE within the socially responsible investment communities have been studied widely by scholars adopting a variety of perspectives. Table 1 shows the main features identified in literature.

TABLE 1: Features influencing SSE - Literature Overview

\begin{tabular}{|c|c|}
\hline Author & Feature \\
\hline $\begin{array}{l}\text { Den Hond \& De } \\
\text { Bakker (2007) }\end{array}$ & $\begin{array}{l}\text { 1) involving consumers through communication and education } \\
\text { 2) firm and industry characteristics } \\
\text { 3) activist tactics }\end{array}$ \\
\hline Goldstein (2011) & $\begin{array}{l}\text { 1) doing one's homework prior to engagement } \\
\text { 2) making sure "the right people" are taking part } \\
\text { 3) being open-minded and willing to listen to the other side } \\
\text { 4) building relationships through transparency and credibility }\end{array}$ \\
\hline Hoffman (1996) & $\begin{array}{l}\text { 1) influence and power of the shareholder } \\
\text { 2) corporate culture and degree to which shareholder request is in line with } \\
\text { that culture } \\
\text { 3) political environment }\end{array}$ \\
\hline $\begin{array}{l}\text { Lee } \quad \& \\
\text { Lounsbury } \\
(2011)\end{array}$ & $\begin{array}{l}\text { To target firms which can incur higher disruption costs and depend more on } \\
\text { reputation. Costs incurred by: } \\
\text { Disruption of routines - to get the attention of management } \\
\text { Framing of issues - to align movement objectives with target firms' } \\
\text { economic interests } \\
\text { Mobilisation of relevant, powerful constituents }\end{array}$ \\
\hline $\begin{array}{l}\text { Logsdon \& Van } \\
\text { Buren (2009) }\end{array}$ & $\begin{array}{l}\text { 1) address an issue meaningful to both } \\
\text { 2) parties involved must be flexible } \\
\text { 3) both must understand each others' needs and constraints }\end{array}$ \\
\hline $\begin{array}{lll}\text { Monks et al } \\
(2004)\end{array}$ & $\begin{array}{l}\text { The ability to keep a proposal on the proxy statement raises awareness } \\
\text { amongst other shareholders and increases pressure on management. } \\
\text { Regulatory changes to improve shareholder rights: transparency and } \\
\text { accountability. } \\
\text { CSR proposals couched in corporate governance language }\end{array}$ \\
\hline $\begin{array}{l}\text { O'Rourke } \\
(2003)\end{array}$ & $\begin{array}{l}\text { Comprehensive and sustained campaign including dialogue and } \\
\text { engagement }\end{array}$ \\
\hline Proffitt & $\begin{array}{l}\text { 1) duration of the campaign } \\
\text { 2) political force of sponsors }\end{array}$ \\
\hline
\end{tabular}




\begin{tabular}{|l|l|}
\hline Spicer (2006) & $\begin{array}{l}\text { 3) relevance to and popularity with broader society } \\
\text { 4) degree of success that similar proposals have had }\end{array}$ \\
\hline Sjöström (2010) & $\begin{array}{l}\text { For shareholders to be successful as norm entrepreneurs they need to } \\
\text { encourage corporations to promote new norms, the use of issue networks } \\
\text { and organisational platforms to increase the resource base }\end{array}$ \\
\hline $\begin{array}{l}\text { Vandekerckhove } \\
\text { et al (2007) }\end{array}$ & $\begin{array}{l}\text { 1) balancing power asymmetries } \\
\text { 2) acknowledging critical rights } \\
\text { 3) negotiating converging and conflicting interests } \\
\text { 5) dialogue must move beyond 'truth-value' }\end{array}$ \\
\hline
\end{tabular}

It is challenging to narrow the large number of features influencing SSE down into broad categories. The literature also contains a bewildering variety of features: reasons for engaging; influence of shareholders on the engagement process; ways of understanding success in SSE; the people involved; the nature of the organisation; and access to knowledge and information, to name just a few. Over half of the scholars stress the importance of identifying those calling the shots (the so-called 'who question') (Goldstein, 2011; Hoffman, 1996; Lee and Lounsbury, 2011; Logsdon and Van Buren, 2009; Proffitt and Spicer, 2006; Vandekerckhove et al., 2007). This is understandable since powerful constituents (Lee and Lounsbury, 2011; Goldstein, 2011) in both the company and on the activist side can shape how SSE is tackled. For example, Vandekerckhove et al. (2007) note that those responding to letters written by shareholders are frequently from communications or investor relations departments rather than core business management. Their study suggests that a response from the CEO indicates that the shareholder is seen as 'strategic' rather than 'general', which surely affects the engagement process.

The 'who-factor' also bears on: actors' knowledge and capabilities; addressing issues (Logsdon and Van Buren, 2009); being well informed on issues (Goldstein, 2011); being able to take discussions beyond mere assertions (Vandekerckhove et al., 2007); being able to balance power asymmetries; acknowledge rights; negotiate converging and conflicting interests (Vandekerckhove, et al., 2007); campaigns on fair wages and other matters (O'Rourke, 2003). Matters bearing on shareholder rights and the use of corporate governance language (Monks, et al., 2004) are also critical. Last but not least, the importance of collaboration and building relationships is also stressed (Vandekerckhove et al., 2008).

\section{Religion, Investing, and Social Shareholder Engagement}


Some religious teachings give particular guidance or advice to ROs for their investing activities. The Catholic, Methodist and Quaker faiths stand out among Christian churches for relying on texts directly linked to the non-financial aspects of investing and shareholder engagement. As with all Christian traditions, the Catholic tradition goes back to the biblical teachings on social and distributive justice. This concern was emphasized again by Pope Benedict XIV in 1745: 'If equality is not maintained, whatever is received over and above what is fair is a real injustice'. One of his successors almost three centuries later, Pope Benedict XVI, stated in his 2009 Caritas in Veritate, a guideline for all bishops, priests and Catholics around the world, that business must shift from the shareholder to the stakeholder model and that business models seeking more than just profit are not only more civilised but also more competitive. The Caritas in Veritate is the most recent amongst the eight encyclicals that have described the Church's development in social approach and deals with corporate responsibility, ethical investment and finance (Melé and Naughton, 2012).

From the first encyclical in 1891 to the most recent topics such as trade-unionism, subsidiarity, globalization and the concept of free markets have been discussed (Cornuel et al., 2010). Practical implications for investing are also found in theological scriptures and their posterior interpretations. John Paul II taught that “... investment always has moral, as well as economic significance" (1991), something that was confirmed by the Vatican as still being valid in 2009, adding that capital can do good but requires due consideration for the way in which it is generated and that no harm to individuals is done. In Caritas in Veritate (Pope Benedict XVI, 2009) we can also read that "What should be avoided is a speculative use of financial resources that yields to the temptation of seeking only short-term profit, [...] and attention to the advancement [...] of further economic initiatives in countries in need of development."(40).

The United Methodist Church, a Protestant movement, draws heavily on 'The Book of Discipline (2012)', developed over 200 years and outlining how United Methodists agree to live their lives together. One paragraph covers responsible investment: “... in the investment of money, make a conscious effort to invest in institutions, companies, corporations, or funds whose practices are consistent with the goals outlined in the Social Principles". This is further elaborated in practical terms with these words: “... endeavour to avoid investments that appear likely, directly or indirectly, to support racial discrimination, violation of human rights, sweatshop or forced labour, gambling, or the production of nuclear armaments, alcoholic beverages or tobacco, or companies dealing in pornography". Besides these guidelines for weeding out unethical investments, The Book of Discipline also includes statements on shareholder engagement: "The boards and agencies are to give careful consideration to shareholder advocacy, including advocacy of corporate disinvestment" (United Methodist Church, 2012).

Among the actors practising SSE, ROs are consistently found to be the most active filers on social and environmental issues (Sjöström, 2010). A study by Louche et al. 
(2012) among over 100 ROs, found that SSE was the most used responsible investment strategy alongside negative screening, positive screening, and impact investing. In particular, $88 \%$ of respondents in the study indicated that they engaged with companies. Recent research shows that $90 \%$ of religious investors believe that active ownership of shares can influence corporate behaviour (Van Cranenburgh et al., 2010). ROs engage with companies through proxy voting, writing letters, filing shareholder resolutions, meeting company representatives, and divesting (Louche, et al., 2012). SSE by ROs is often carried out in partnership with like-minded faith organizations, grouped in religious investor associations. The Interfaith Center on Corporate Responsibility (ICCR) in the USA is the largest network, with over 300 members representing $\$ 100$ billion in invested capital. Another significant group is the UK-based Church Investors' Group (CIG), with combined assets of $£ 12-13$ billion. Their collaborative strategies make them highly relevant to management (Glac, 2010). An oft-cited example is SSE during Apartheid in South Africa in the 1980s and early 1990s. However, collaboration also entails challenges. For example, it has been reported how Catholic religious orders in the U.S. struggled with setting criteria and strategies for pursuing their concerns with the corporations they invested in (Purcell, 1979; Wokutch, 1984).

A few studies have addressed the specific features of ROs and the way they shape the approach to SSE. ROs are known for their patience as well as their collaborative and persistent approach in SSE (Clark, et al., 2008; Proffitt and Spicer, 2006; Rojas, et al., 2009). Besides, ROs are driven by their moral beliefs and religious values (O'Rourke, 2003; Sparkes and Cowton, 2004; Tkac, 2006). These references to a set of beliefs suggest that ROs, when practising SSE, may be at an advantage compared to other investors. This study sheds light on the religious features influencing ROs' SSE practices.

\section{The Religious Organisations Studied}

Having reviewed the link between SSE and ROs according to the existing literature, in this section, we describe briefly the three ROs used in this study.

The Quaker-based Joseph Rowntree Charitable Trust [hereinafter referred to as The Quakers] is a relatively small UK-based trust with an endowment of £150-200 million but which is noted by experts in the sector as being at engagement's cutting edge. The endowment is invested through an independent investment management company chosen because of its willingness to put in practice The Quakers' ethical investment policies and engagement criteria. Key ethical decisions and engagement activities are undertaken by an investment committee, which comprises six Quaker trustees and a cooptee experienced in finance. More routine engagement falls to The Head of Finance. Quakers are particularly concerned with peace, equality and integrity issues. Besides these issues being reasons to engage, the main source of engagement initiatives comes 
from reflection on Quaker testimonies and on those current issues they consider to be most pressing.

With headquarters in Rome, The Missionary Oblates of Mary Immaculate is a global international missionary congregation belonging to the Catholic Church, which is present in 67 countries around the world and has trusts and endowments totalling $\$ 450$ million assets under management. The US Oblates for Justice, Peace and Integrity of Creation office [hereinafter termed The Oblates] based in the US, co-ordinates the Faith Consistent Investing Program and is responsible for shareholder engagement and advocacy activities focussing mainly on the US. It is widely recognised to be very active in terms of engagement. The decision to wield influence through investments was based on Catholic teachings from The Second Vatican Council and the 1971 Synod of Bishops "Justice in the World" and it has led to a focus on social justice.

The Ethical Investment Advisory Group of the Church of England is responsible for directly engaging with companies as well as developing and advising on ethical policy for the three main investing bodies of the Church of England. These bodies manage combined assets of around $£ 8$ billion. It sees itself as an institutional investor, making a sharp differentiation between its position and the more activist position taken by other engagers such as The Oblates. A comprehensive ethical investment policy has been developed in line with the values of the Church for key issues such as the environment, corporate governance, and HIV/AIDS. The Ethical Investment Advisory Group of the Church of England [hereinafter referred to as The Church of England] brings together investors, theologians, members of the General Synod and Archbishops Council. It firmly believes in acting as good stewards and as responsible investors.

\section{Methodology}

We adopted a qualitative exploratory approach using seven cases of engagement by ROs. A descriptive case study approach permits the researcher to explore more meaningful aspects of real life behaviour in the particular context they occur (Yin, 2003). Particularly for enriching understanding of the processes in responsible investment and for complex and long-term shareholder engagement, case study research is valuable (Sparkes and Cowton, 2004; Sjöström, 2008). We did not aim to study the differences of the ROs beliefs and SSE practices but rather we focused on what they had in common. The study focused on creating knowledge from best practices. The analysis was done at the organisational level as well as case-by-case which implies the multiple embedded case design as described by Yin (1994). The research on organisational level provided a richer picture of the individual cases and ensured they were analysed in the context of the ROs. This chapter balanced the views of the four authors, allowing triangulation of perspectives as a way to improve the validity of the findings (Yin 1994; Eisenhardt 1989). 


\section{Sample}

For the purpose of this study we selected three Christian Organisations: a Quaker organisation, the Joseph Rowntree Charitable Trust; a Catholic organisation, the Missionary Oblates of Mary Immaculate; and an Anglican organisation, the Church of England. We chose those three organisations because experts recognized them as examples of relevant ROs involved in SSE. They all had over 20 years of experience in engagement with companies on social and environmental issues. Despite the significant difference of assets under management, ranging from $£ 150$ million to $£ 8$ billion, they all had an organisational separation between financial decision-making and social decisionmaking. The social screens and engagement was organised after financial decisionmaking had taken place. Therefore, as described above, these organisations did not renounce profits per se; it only means that higher returns were not their major concern.

By analysing their cases of engagement, we could confirm their SSE was indeed influenced by several features that closely link to their religious nature. We analysed the features influencing their SSE practices and found that they considered their religious features as contributors to creating social change.

\section{Data Collection}

Interviews, follow up conversations, investment statements of the organisations and related organisations' websites, annual reviews, resolutions, engagement progress reviews, recommendations from NGOs, press releases and other archival data ${ }^{1}$ sources were used to secure validity and accuracy and to build evidence-based cases. Data collection was done over a one-year period, from mid-2011 to mid-2012. Two researchers conducted a total of five interviews with shareholder engagement experts familiar with the work of ROs in Europe and the US and held six semi-structured interviews with the main representatives responsible for engagement within the ROs studied $^{2}$. The literature (Sparkes and Cowton, 2004; Sjöström, 2008) was used as a basis for drafting the interview protocol. The interview protocol was developed based on 'how' and 'why' questions and was reviewed by peers familiar with the topic and refined several times to incorporate their feedback. Simultaneously, reports, resolutions, press releases, statements and other publically available data of the three ROs as well as the related organisations were investigated to enrich the data. Sample questions were

\footnotetext{
${ }^{1}$ All the data and documents are available upon request.

${ }^{2}$ We have had interviews with representatives of the religious organizations we studied and with experts. In total we had 11 interviews, involving 9 different people. We had two series of interviews with each of the three ROs bringing the total of interviews with the case study representatives to 6 . In one of the ROs, The Quakers, we interviewed two representatives, the Head of Finance and the Chair of the Investment Committee. Therefore we had 6 interviews with 4 interviewees from ROs and 5 interviews with experts in the field of faith investing.
} 
sent to the ROs via e-mail before the interviews. Archival data from religious investor groups, the ROs involved, and the related media publications on the cases contributed to the reliability and verification of the study and familiarisation with the subject matter. Follow-up conversations were held with all three organisations to review and complete the missing information. These follow-up conversations were done with additional staff members involved in engagement as well as the interviewees themselves. Triangulation of sources was done to corroborate the facts o(Yin, 1994).

The ROs represented comparable but differing characteristics which is in line with Eisenhardt's (1989) emphasis on theoretical sampling. Details of these organisations, the cases, and those interviewed are given in Table 2.

TABLE 2: Selected Case Summaries

\begin{tabular}{|c|c|c|c|}
\hline & $\begin{array}{l}\text { Joseph Rowntree } \\
\text { Charitable Trust, } \\
\text { UK }\end{array}$ & $\begin{array}{l}\text { Missionary Oblates } \\
\text { of Mary } \\
\text { Immaculate, US }\end{array}$ & $\begin{array}{l}\text { Ethical Investment } \\
\text { Advisory Group, Church } \\
\text { of England, UK }\end{array}$ \\
\hline Denomination & Quaker & Catholic & Anglican \\
\hline Congregation & $\begin{array}{l}\text { UK based, Quaker } \\
\text { worldwide }\end{array}$ & $\begin{array}{l}\text { Italy/US based, } \\
\text { worldwide }\end{array}$ & $\begin{array}{l}\text { England based, Anglican } \\
\text { worldwide }\end{array}$ \\
\hline $\begin{array}{l}\text { Engagement } \\
\text { experience }\end{array}$ & formally since 1970 s & $\begin{array}{l}\text { formally since } 1980 \mathrm{~s}, \\
\text { (engaged since } \\
\text { 1970s) }\end{array}$ & $\begin{array}{l}\text { formally since } 1994 \\
\text { (engaged prior to this) }\end{array}$ \\
\hline $\begin{array}{l}\text { AUM } \\
\text { (approx.)* }\end{array}$ & $£ 150-200$ million & $\$ 450$ million & $£ 8$ billion \\
\hline $\begin{array}{l}\text { Investment } \\
\text { focus }\end{array}$ & $\begin{array}{l}\text { UK and European } \\
\text { listed, small-mid cap }\end{array}$ & $\begin{array}{l}\text { US listed, small- } \\
\text { large cap. }\end{array}$ & $\begin{array}{l}\text { Mostly UK listed, small- } \\
\text { large cap. }\end{array}$ \\
\hline Companies held & 100 & 600 & 2000 \\
\hline $\begin{array}{l}\text { Annual } \\
\text { engagement } \\
\text { (approximately) }\end{array}$ & 5-10 companies & $\begin{array}{l}\text { resolutions voted, } 45 \\
\text { letters, } 60 \text { company } \\
\text { engagements }\end{array}$ & $\begin{array}{l}\text { resolutions voted, } 200 \\
\text { letters (UK), } 50 \text { company } \\
\text { engagements }\end{array}$ \\
\hline $\begin{array}{l}\text { Social } \\
\text { Shareholder } \\
\text { Engagement } \\
\text { Cases studied }\end{array}$ & $\begin{array}{l}\text { 1) Reed Elsevier } \\
\text { Publishing: to stop } \\
\text { involvement in arms } \\
\text { fairs. }\end{array}$ & $\begin{array}{l}\text { 1) Goldman Sachs: } \\
\text { to become more } \\
\text { transparent on the } \\
\text { risks of financial }\end{array}$ & $\begin{array}{l}\text { 1) Supermarkets: to gain } \\
\text { fairer treatment for small } \\
\text { farmers on industry level } \\
\text { in the UK. }\end{array}$ \\
\hline
\end{tabular}




2) Vedanta Mining:
meeting human rights
and environmental
standards at Orissa
plant, India.

Interviewed products.

2) Newmont Mining: to report on social impact and engagement with communities.

3) Bank of America: to develop and implement ethical criteria for lending.

\section{Head of Finance and} the Chair of the Investment Committee
Director of the US Justice, Peace and Integrity of Creation office
2) Vedanta Mining: to meet ethical social standards at Orissa plant, India.
Chairman of the Ethical Investment Advisory Group

\section{*AUM $=$ Assets Under Management}

We structured the interviews in seven parts, starting with questions on case details, then covered the decision-making process and the reasons behind the decisions, followed by questions on religious beliefs and structures that may have shaped events. Next, we discussed the interviewees' objectives and processes in relation to the target company. Last, we asked interviewees to argue why the case was successful or not. The cases discussed were chosen by the interviewees. Prior to the interview, we asked them to select two or three cases which were either successful or not.

\section{Data Analysis}

The analysis focused on the interviews and was triangulated with archival data. Coding of the interview transcripts enabled identification of the most frequently-mentioned and stressed features influencing engagement processes. The qualitative analysis software package used, Nvivo 9, facilitated fast, rigorous processing of the vast amount of information gathered and transcribed (Easterby-Smith et al., 2002; Seale, 2003). The analysis enabled us to identify the dominant features that played a role in the engagement processes. The features were defined by having three researchers independently analysing and categorizing the data using different software (amongst which NVivo 9) and coding techniques without having discussed potential categories beforehand. After several iterations and agreeing on the categories, the three independent researchers coded the interviews, achieving a high inter-rater reliability, providing confidence in the value of the classification process. 


\section{Findings}

The following five features influencing the SSE of ROs were identified: collaboration, contact with top management, structured belief system, grassroots network, and longterm perspective. The first two features were already identified in previous research (see table 1) while the last three are new and can be linked to the religious nature of ROs.

Collaboration with other shareholders and stakeholders was regarded as a major influencing feature. Collaboration can work in several ways; whilst it usually contributes to the influence or power of the collaborators, it sometimes proved inhibitory. Without having defined the term 'collaboration', all interviewees referred to intra- and interreligious collaboration, referring to their collaboration with religious investor groups. This is in line with the findings of Louche et al (2012) that ROs are affiliated with religious groups rather than that they join secular initiatives. The Oblates worked closely with a religious investor group (ICCR) on all the engagement processes and the Director of the Oblates said "Working with other partners is just in our DNA, none of us can adequately do it alone", "they bring diversity, experience, real life stories and their own research capacity". He noted that collaboration also provided a better balance in terms of the strategy chosen to engage a corporation but also "a broader base of experience and knowledge in terms of the issues". The Quakers, in the Reed Elsevier case, collaborated with the Campaign Against Arms Trade which has its Christian Network $^{3}$ as well as through EIRIS, the Quaker-originated global network of responsible investors. Also, the Quakers worked in collaboration with other members of the Church Investors Group (CIG). It offered "the benefits of scale and knowledge" acknowledging that "We're still a small organisation so it's helpful to be able to share research". The Quakers highlighted the value of combined shareholdings when asking to meet a big company. They stated that "the size of the shareholdings that the churches have together tends to mean that you get more senior people in the company". Also the Church of England said that they sometimes engage with the CIG to get a bigger say in certain issues.

However collaboration was not seen as a benefit per se. The Church of England stated, "In the main where we can, we engage on our own" preferring private dialogue and saying that "It's much easier to get a very clear position just within our group". In some instances, collaboration involved compromises, as pointed out by the Quakers: "There could be instances when you have to compromise your positioning because people perhaps weren't as prepared to take things as far as you might". Although the literature claims that ROs represent a homogeneous group of investors (Sparkes and Cowton,

\footnotetext{
${ }^{3}$ http://www.caat.org.uk/get-involved/christian/ (accessed 8/11/2013)
} 
2004), these statements show that diversity among ROs may make collaboration difficult. Acting on their own also allowed some of them to take decisions faster. The Quakers had experienced this and stated "The larger the collaborative body, ... the more complex it is to work together". Yet, it was also noted that the increasing global nature of the issues they were engaging in sometimes required collaborative engagement. Working together can be a learning process in itself, as recognised by the Quakers: "The collaborative way of working will get better and better and become more and more important".

Contact with top management was identified by all three organisations as an important feature for continuing engagement. The Oblates: "The fact that we wanted to meet with the people at the highest levels of the company" was of key importance in the Goldman Sachs case. As a matter of fact, The Oblates had chosen to invest in Goldman Sachs despite it being on their exclusion list based on the Oblates' beliefs. Influencing management was the reason to become a shareholder in the first place. The Oblates, with a limited number of shares in Goldman Sachs, filed a resolution in 2009 which opened the door for contact with top management. The request in the resolution focused on Goldman Sachs to be transparent on management information system, procedures, risk management practices, governance and supervision. In the Reed Elsevier example the Quakers said "We always write to the top" contrary to meeting with the corporate social responsibility representatives: "They [the corporate social responsibility team] are not people with a great deal of influence within the company...they are not going to change anything". Similarly, the Church of England stated: "The Chairman is often the most useful place to go as well as being the appropriate one”, whilst CSR departments seemed to approach issues in a more legalistic and less substantive way, as if "someone's just trying to clear it off their desk".

The first new feature of the ROs engagement was their structured belief system. The sets of historical, continual and unwavering religious principles, more broadly presented here as 'having a structured belief system', are a basic starting point and continuous guidance in the Christian organisations' investment policies and practices. Their beliefs and practices united them into one single moral community [the Church] and all those who adhere to it. The Church of England stated its ethical investment considerations form an integral part of the Church's "witness and mission" (Church of England, 2011) and underlined how "in each different area of policy there will be specific teachings". From The Oblates' standpoint, being an RO "gives us a moral compass" which helped in engagement. The unified system of beliefs and practices related to sacred things, following Durkheims' (1965) definition of religion ${ }^{4}$, guided the ROs in their engagement as it did in all aspects of life: the Quakers explained that "Quakers very

\footnotetext{
${ }^{4}$ In "The Elementary forms of Religious Life", Durkheim (1965; pp 230-32) defines religion as "A unified system of beliefs and practices relative to sacred things, i.e., things set apart and forbidden--beliefs and practices which unite in one single moral community called a Church, all who adhere to them.'
} 
much see things holistically", "We don't distinguish between what is sacred and what's secular, we say everything is sacred ... our whole planet is precious". The Oblates also suggested that their broader concern for issues at a "systemic" or societal level led to an interest in more complex, intangible issues. He claimed that these issues were "not always something that RI investors or others will pick up on because (they don't) involve an immediate tangible environmental or social issue".

A second new feature of ROs engagement was their close contact with their grassroots networks. A grassroots network in this setting is one driven by the religion of a community. The term implies that the creation of the network and the group supporting it are natural and spontaneous, and the group distinguishes itself from another community or network. Grassroots networks are at the local level, as many believers in a community give their time to support the local church, which can lead to helping the religious denomination as a whole. For instance, a grassroots network can lead to significant financial contribution to the church, but also provide voluntary support of activities. Grassroots were united by a structured and shared belief system. They were considered to facilitate the engagement of the Christian organisations: "Given the geographical breadth of the Church of England we often pick up information before it reaches companies' boards in the UK'. The Church of England mentioned the uniqueness of having people on the ground by stating "[Our grassroots network] gives us a level of intelligence on issues that otherwise we wouldn't have and I think most investors wouldn't have" and "The key issue was the disconnect between the claims of the company and what we saw and heard [from our grassroots] on the ground". The Oblates, who state to have justice, peace and sustainable environment internalized throughout their grassroots organizations in over 65 countries (Missionary Oblates, 2012), even mentioned local access to knowledge as a criterion for engagement: "We don't often like to engage a company unless we do have some actual contact on the ground with local communities". These networks were the sources of knowledge on controversial issues and led to engagement with Vedanta: "It was brought to our attention originally by members of the Church locally to Vedanta's operations in India" (Church of England). Its Chairman recognised that "What was very helpful was the kind of intelligence that was gathered from the Church at the grassroots level locally". Whilst we did not research potentials for conflicts of interest of church members being employees or business partners (or the risk of insider trading occurring), we note that church members may wear several hats. If they were to share confidential information in the church community because they were informed as employees it could result in a potential breach of business codes of conduct. The grassroots networks were not only about signalling issues but also provided access to local communities and NGOs. ROs networks cover many countries, often ones where it is hard to get information through conventional news sources: "Though we are small, we have missionaries in about 67 countries around the world... about 47 of those who come from the so-called developing world" (The Oblates). 
Having a structured belief system is closely linked to the third new feature, a long-term perspective. The Oblates initially had some difficulty in identifying an unsuccessful engagement as their long-term perspective resulted in cases continuously remaining on their radar, rather than being closed as successful or unsuccessful. "We keep asking over a period of time and in some ways the circumstances, the personalities, or the market changes ...can do it". This on-going nature of engagement was summed up when he stated "We have been at this for a long time and intend to be at it for a long time". One of the reasons given by the Church of England for engaging with companies was to keep ethical issues on the table. In this way, over the long-term the broad societal mission of the ROs became an objective for engaging with corporations. The time perception of these ROs might differ sharply from that of ordinary, secular investors. It was noted by The Oblates: "We have been around for a couple of hundred years as an organisation so it is not like we have a campaign that is going to finish in a year or something to accomplish and then we will go out of business". This long-term perspective gave them the strength to be persistent, patient and grasp opportunities that they might otherwise miss: “...What sometimes may have been impossible under one CEO becomes possible under another one..." (The Oblates).

\section{Discussion and Conclusion}

In seeking to overcome the limitations of the neo-liberal capitalist system, Knyght et al. (2011) proposed socialized capital supported by investment horizons of 30 years or more (p. 7). Interventions and new frameworks are suggested in terms of increasing the number of actors from agents and shareholders only, to stakeholder (state, NGOs, civil society) models. This chapter suggests that one of the solutions for unethical business behaviour can be found in the role ROs can play as shareholders. This study advances Kreander's (2004) findings that nowadays SSE practices of ROs are influenced by features that can be linked to the religious nature of their being.

Over the last decade, several theological leaders have given guidelines for grassroots community members on how to invest in keeping with their faith. The recent Caritas in Veritate by Pope Benedict XIV (2009) as well as the recently revised United Methodist Book of Discipline (2008) urge ROs to invest responsibly and practise SSE. Besides the growing number of religious documents on the topic of faith and investing, the empirical part of this study identified three features that influence ROs' SSE, namely: (1) the grassroots network; (2) a structured belief system; (3) the long-term perspective. These features can be considered as characteristic of Christian organisations. However, the focus of this study was on how the ROs features influence the SSE practices, not how they differed from other active social shareholders. This would make an important object for future research. Furthermore, the interest of ROs participating in activities of religious investor groups such as the ICCR and CIG, reveal ROs' growing interest in squaring the sacred and secular worlds. 
Obviously, challenges in integrating faith and investing remain. As mentioned by the Quaker interviewee 'Quakers view the world as being interconnected and see things holistically'. Nevertheless, they still have to face some thorny dilemmas given that they can never fully apply their religious principles: 'It would be hypocritical to just say we're not going to invest in mining companies but still continue to use equipment made of aluminium or steel', the Quaker interviewee went on to say. Engaging with mining companies was regarded as a way to practise faith to improve things rather than expressing one's discontent by divesting. In another Quaker case, divesting was used and turned out to have the desired effect as well. Improving business practices through SSE seems to be a compromise for ROs and is seen as the lesser of two evils. Also the Church of England indicated 'It would be a delusion to think that the Church can act with entirely clean hands in the area of investment' (quote extracted from Kreander et al., 2004; p 428). In our study the ROs considered investing as compatible with faith but that investing for profits only was no option. As The Oblates put it:' If we own shares, we feel and believe that we are obliged to own them actively and responsibly' and 'as faith-based investors we believe that our investment decisions and engagements have to be consistent with what we believe'. For The Oblates, the Catholic principles of care of creation, good stewardship and the role of engaging with the world have proven major factors in the way they practise SSE.

Besides challenging the sacred-secular divide, our three newly-identified features contribute to existing literature on SSE insofar as they add to the features influencing SSE. We find Christian ROs are able to establish ethical investment practices justified by their doctrinal teachings. Such doctrine (Stark, 1996) reflects their structured belief system and purpose as an organisation. In turn, the structured belief system provides such a strong foundation that it distinguishes them from most other responsible investors. Mutual funds, pension funds and institutional investors for example often lack a historical, unified identity and thus must continually justify their engagement choices to customers or to larger audiences. The Christian ROs studied however, share a strong belief system which shapes their thinking, arguing and operating that receives much resonance amongst its community members and that gives the SSE representatives the required conviction to approach management teams and address issues of concern stemming from their belief system.

The grassroots networks were identified as characterizing the way ROs practise SSE. Kreander already noted the role of clergy in challenging the secular practices of their churches by stressing that criticism of church investment policies had waned after new ethical policies were implemented (Kreander et al., 2004; 417). From a different angle, and more prominently in our study, grassroots provide valuable information gleaned from churches or missionaries in areas where corporations do business. Since grassroots members share a similar belief system as the engagers at the ROs, there is a benefit to having this first-hand link between the engagers and the grassroots. 
Finally, the three ROs noted that it was important that their actions and decisions be consistent with their belief system and that this gave them a long-term perspective. Since their set of beliefs is not easily shifted (Van Cranenburgh et al quoting Victoria Heath, EIRIS 2012), their SSE activities over time show consistency. Proffitt and Spicer (2006: 167) already hinted to the moral motivation and long-term horizon of ROs. The processes of engagement researched in our study took about three years on average and over eight years in one case. The significance of the process over a longer period of time was emphasised by The Church of England: "That's the interesting thing about engagement, ... a process which is unsuccessful at the time may actually end up being successful as well". Engagement can be understood as comprising various different tactics and being influenced by varying factors over the long term. The patience (Proffitt and Spicer, 2006) and persistence (Clark, et al., 2008; Rojas, et al., 2009) shown by ROs allows them to exploit opportunities as they arise and leads to a learning process which can be applied to future engagement.

\section{Limitations and implications for future research}

As with all research, this study had its limitations. We chose three ROs for their relevance and comparative features but this limited sample size makes it hard to generalise the research findings. Additional quantitative research could be useful; however, it would be difficult to find a large sample as, despite some growth in faith consistent investing, it is still not commonplace amongst ROs in Europe. Christian UK and US contexts were selected for their high level of engagement; however, more research is needed on other countries, religions, denominations and contexts as regulatory, religious and cultural differences may have a critical impact on engagement processes. Further, it was difficult to identify the specific principles to be respected by each organisation and appraise how they were implemented in each case study. Also, it is assumed in this chapter that ROs are sincere about their desire to improve social and environmental conditions. That said, some might raise doubts about their ethical objectives and/or the social impact of their engagement. Whilst we triangulated the statements made by the RO representatives in the interviews with archival data, we did not interview the management of the companies involved or other stakeholders in the engagements. This chapter looks at things from the engagers' standpoints. The viewpoints of the companies on the receiving end of engagement were not taken into consideration. Research into the firm perspective of their engagement with ROs would be valuable in gaining a fuller picture of the factors influencing SSE. Finally, some more research could be done regarding each of the features identified in our research. For example, we did not take into account the risk of insider trading when grassroots members are employed or business partners of the companies that were approached in the engagements. 
The Christian ROs that participated in our study were actively involved in SSE and their way of doing SSE was influenced by features that stem from the religious nature of these entities. Through this chapter we aim to explore the discussion about ROs' potential to practise their faith by means of their investments, rather than keeping both issues separate. We broadened the discussion about faith and investment by including features of ROs which influence the way they practise SSE. ROs that are not yet investing in line with their beliefs or that are not utilising their features can learn from this and review their potentials as faith consistent investors. Various ROs are increasingly mindful of the power they can wield as active shareholders. From a sociological rather than a philosophical viewpoint, Christian ROs, with their unwavering belief system, extensive grassroots networks and long-term approach, are a force to be reckoned with in the engagement field. 


\section{References}

Admati A.R. and Pfleiderer P.C. (2009), "The 'Wall Street Walk' and Shareholder Activism: Exit as a Form of Voice.”, The Review of Financial Studies, Vol. 22, pp. 2445-2485.

Anderson K., Ramsay I., Marshall S. and Mitchell R. (2007), "Union Shareholder Activism in the Context of Declining Labour Law Protection: four Australian case studies.", Corporate Governance: An International Review Vol. 15 No. 1, pp. 4556.

Arjaliès, D. (2010) A Social Movement Perspective on Finance: How Socially Responsible Investment Mattered, Journal of Business Ethics, 92, 57-78.

Baxter, R. (1825) A Christian Directory or Body of Practical Divinity. A Summ of Practical Theologie and Cases of Conscience (1673). ed. J. Tawney, London: G. Bell \& Sons.

Booth, P. (1993), "Accounting in Churches: A research framework and agenda.", Accounting, Auditing \& Accountability Journal Vol. 6 No. 4, pp. 37-67.

Central Finance Board (2013), "Perseverance Works", Central Finance Board of the Methodist Church, Annual Report 2013.

Clark G.L., Hebb T. (2004), "Pension Fund Corporate Engagement: The Fifth Stage of Capitalism.”, Industrial Relations Vol. 59 No. 1, pp. 142-171.

Church of England Website. (2010), http://www.churchofengland.org/mediacentre/news/2010/02/pr2010.aspx [3 July 2012]

Church of England, Ethical Investment Advisory Group, Statement of Ethical Investment Policy, November 2011.

Cornuel E., Habisch A. and Kletz P. (2010), "The practical wisdom of Catholic social teachings", Journal of Management Development Vol.29, pp 747-754.

Cracknell, K. and White, S.J. (2005) An Introduction to World Methodism, Cambridge University Press. Cambridge, UK.

Den Hond F. and De Bakker F.G.A. (2007), "Ideologically Motivated Activism: How Activist Groups Influence Corporate Social Change Activities.", Academy of Management Review Vol. 32, pp. 901-924. 
Duncan J., Flesher D. and Stocks H. (1999), "Internal control systems in US churches", Accounting, Auditing \& Accountability Journal Vol. 12 No. 2, pp. 142-63.

Durkheim E., (1965), "The Elementary forms of Religious Life". New York. The Free Press, pp. 230-32.

Easterby-Smith M., Thorpe R. and Lowe A. (2002), Management Research, 2nd ed. Sage: London.

Eisenhardt K.M. (1989), "Building Theories from Case Study Research." Academy of Management Review Vol. 14 No. 4, pp. 532-550.

Eurosif. (2006), European SRI Study, http://www.eurosif.org/images/stories/pdf/eurosif_sristudy_2006_complete.pdf [29 July 2012]

Eurosif (2012), European SRI Study, http://www.eurosif.org/research/eurosif-sristudy/sri-study-2012 [12 November 2013]

Glac K. (2010), "The Influence of Shareholders on Corporate Social Responsibility.", Center for Ethical Business Cultures pp. 1-38.

Goldstein M. (2011), "The State of Engagement between US Corporations and Shareholders", IRRC Institute.

Goodman, J., Louche, C., van Cranenburgh, K. C. \& Arenas, D. forthcoming. 'Social Shareholder Engagement: The Dynamics of Voice and Exit.' Journal of Business Ethics. BUSI-D-13-00268R1

Guay T., Doh J. and Sinclair G. (2004), "Non-governmental Organizations, Shareholder Activism, and Socially Responsible Investments: Ethical, Strategic, and Governance Implications.”, Journal of Business Ethics Vol. 52 No. 1, pp. 125-139.

Hoffman A.J. (1996), "A Strategic Response to Investor Activism.”, MIT Sloan Management Review Vol. 37 No.2, pp. 51-64.

Knyght, P.R., Kakabadse N.K., Kouzmin A. and Kakabadse A. (2011), "Chronic limitations of neoliberal capitalism and oligopolistic markets: An urgent case for socialized capital.", Society and Business Review, Vol. 6, No. 1, pp. 7-26.

Kreander N., McPhail K. and Molyneaux D. (2004), “God's fund managers: A critical study of stock market investment practices of the Church of England and UK Methodists.", Accounting, Auditing and Accountability Journal, Vol. 17 No.3, pp. 408-441. 
Leavey G. and King M. (2007), "The devil is in the detail: partnerships between psychiatry and faith-based organisations.", The British Journal of Psychiatry, Vol. 191, pp. 97-98.

Lee M.-D.P. and Lounsbury M. (2011), "Domesticating Radical Rant and Rage: An Exploration of the Consequences of Environmental Shareholder Resolutions on Corporate Environmental Performance.”, Business and Society, Vol. 50 No.1, pp. 155-188.

Logsdon J. and Van Buren H. (2009), "Beyond the Proxy Vote: Dialogues Between Shareholder Activists and Corporations", Journal of Business Ethics, Vol. 87 No.1, pp. 353-365.

Louche C., Arenas D. and Van Cranenburgh K.C., (2012), "From Preaching to Investing: Attitudes of Religious Organisations Towards Responsible Investment", Journal of Business Ethics, Vol. 110, No. 3, pp. 301-320.

Lydenberg S. (2007), "Universal Investors and Socially Responsible Investors: a tale of emerging affinities”, Corporate Governance: An International Review, Vol. 15, pp. 467-477.

Marens, R. (2004), "Waiting for the North to Rise: Revisiting Barber and Rifkin after a Generation of Union Financial Activism in the US", Journal of Business Ethics, Vol. 52 No.1, pp. 109-123.

Mele D. and Naughton M. (2012). "The Encyclical-Letter "Caritas in Veritate": Ethical Challenges for Business". Journal of business ethics, DOI 10.1007/s10551-0111180-7

Monks R., Miller A. and Cook J. (2004), "Shareholder activism on environmental issues: A study of proposals at large US corporations (2000-2003).", Natural Resources Forum, Vol. 28, No. 317-330.

Missionary Oblates of Mary Immaculate. (2012), Oblates Website [21 September 2012] http://omiusajpic.org

Noonan Jr. J.T. (1957), “The Scholastic Analysis of Usury”, Cambridge, MA: Harvard University Press.

O'Rourke A. (2003), "A new politics of engagement: shareholder activism for corporate social responsibility.", Business Strategy and the Environment, Vol. 12 No.4, pp. 227-239.

Pope Benedict XVI, (2009), Caritas in Veritate (Libreria Editrice Vaticana, Vatican City). Vatican $\quad$ Website $21 \quad$ September 2012] 
www.vatican.va/holy_father/benedict_xvi/encyclicals/documents/hf_benxvi_enc_2 0090629_caritas-in_veritate_en.-html.

Proffitt W.T. and Spicer A. (2006), "Shaping the shareholder activism agenda: institutional investors and global social issues.", Strategic Organization Vol. 4 No.2, pp. 165-190.

Purcell T. (1979), "Management and the 'ethical' investors.", Harvard Business Review September-October, pp. 24-44.

Riyanto Y.E. and Toolsema L.A. (2007), "Corporate Social Responsibility in a Corporate Governance Framework.", SSRN eLibrary.

Rojas M., M'Zali B., Turcotte M.-F. and Merrigan P. (2009), "Bringing About Changes to Corporate Social Policy through Shareholder Activism: Filers, Issues, Targets, and Success.", Business and Society Review, Vol. 114 No.2, pp. 217-252.

Seale C. (2003), “Computer-assisted analysis of qualitative interview data.”, In Inside Interviewing: New Lenses, New Concerns, Gubrium J., Holstein J. (eds). Sage: London, pp. 289-308.

Sjöström E. (2010), "Shareholders as Norm Entrepreneurs for Corporate Social Responsibility.”, Journal of Business Ethics, Vol. 94 No.2, pp. 177-191.

Sparkes R.., Cowton C.J. (2004), "The Maturing of Socially Responsible Investment: A Review Of The Developing Link With Corporate Social Responsibility.”, Journal of Business Ethics, Vol. 52 No.1, pp. 45-57.

Stark R. (1996), "Why religious movements succeed or fail: A revised general model.", Journal of Contemporary Religion, Vol. 11, pp. 133-146.

Tkac P. (2006), "One Proxy at a Time: Pursuing Social Change through Shareholder Proposals.”, Economic Review, Federal Reserve Bank of Atlanta, pp. 1-20.

UN. (2009), London, England, 3 November 2009 - Secretary General's speech to Summit of Religious and Secular Leaders on Climate Change [as prepared for delivery]: www.un.org/apps/sg/sgstats.asp?nid=4204 [28 November 2011]

United Methodist Church. (2012), "The Book of Discipline of the United Methodist Church.", The United Methodist Publishing House. Nashville, Tennessee. http://tinyurl.com/book-of-discipline [18 May 2013]

USSIF. (2010), "Report on Socially Responsible Investing Trends in the United States.", Washington: Social Investment Forum Foundation. 
Van Cranenburgh, K.C., Arenas D., Louche C., Vives J. (2010), "From Faith to Faith Consistent Investing: Religious Institutions and their Investment Practices."

Van Cranenburgh K.C., Goodman J., Louche C., Arenas D. (2012), "Believers in the Boardroom, Religious Organisations and their Shareholder Engagement Practices."

Vandekerckhove W., Leys J., Van Braeckel D. (2007), “That's not what happened and it's not my fault anyway! An exploration of management attitudes towards SRIshareholder engagement.”, Business Ethics: A European Review, Vol. 16 No.4, pp 403-418.

Vandekerckhove W., Leys J. and Van Braeckel D. (2008), “A Speech-Act Model for Talking to Management. Building a Framework for Evaluating Communication within the SRI Engagement Process.", Journal of Business Ethics, Vol. 82 No.1, pp. 77-91.

Weber, M. (1920), Die Protestantische Ethik. Eine Aufsatzsammlung, Tubingen:Verlag J.C.B. Mohr

Waygood S, Wehrmeyer W. (2003), "A critical assessment of how non-governmental organizations use the capital markets to achieve their aims: a UK study.", Business Strategy and the Environment, Vol. 12 No.6, pp. 372-385.

Wokutch R. (1984), "Ethical investing: an empirical study of policies and practices of Catholic religious institutions.", Akron Business and Economic Review, Vol.15 No.4, pp. 17-24.

Yin R.K. (1994), "Case Study Research: Design and Methods.", Thousand Oaks, California: SAGE.

Yin, R. K., (2003). Case Study Research: Design and Methods. 3rd edition”. Thousand Oaks, California: SAGE. 